\title{
Tras los pasos de Amélie: de Montmartre al resto de París
}

\author{
Behind Amélie's steps: \\ from Montmartre to the rest of Paris
}

\author{
MÓNICA TOVAR VICENTE \\ Universidad Complutense de Madrid \\ Monica.tovar.vicente@gmail.com
}

Recibido: $17 / 02 / 2013$

Aceptado: 22/03/2013

\begin{abstract}
Resumen
Desde su llegada a las pantallas cinematográficas en el año 2001, Le fabuleux destin d'Amélie Poulain (Amélie para el caso español), la película coescrita y dirigida por JeanPierre Jeunet, ha promocionado de manera evidente la parte alta de la capital francesa: el parisino barrio de Montmartre acoge diariamente a numerosos turistas que desean visitar aquellos espacios que coprotagonizan el relato con la enigmática camarera de Les deux moulins. Sin embargo, el análisis del texto fílmico revela que las imágenes que lo integran han sido rodadas en, prácticamente, todos los distritos de la ciudad. Con este trabajo se quiere explicar cómo el quartier (barrio) indicado ha potenciado el acento cinematográfico que posee desde entonces e, igualmente, cómo los diferentes componentes del relato conceden al espectador pistas que, una vez sumadas y estructuradas, revelan una guía turística que le invita a perderse en la realidad compleja de la urbe.
\end{abstract}

\section{Palabras clave}

París, Amélie, "ville lumière", arrondissement, Montmartre, $18^{\text {ème. }}$ 


\begin{abstract}
After being released in the cinemas in 2001, Le fabuleux destin d'Amélie Poulain (Amélie, English title), the film co-written and directed by Jean-Pierre Jeunet, has promoted in an evident way the high area of the French capital: the Parisian neighborhood of Montmartre is visited daily by tourists coming from all over the world and who desire to take photos of all the localizations which appeared with Les deux moulins' enigmatic waitress. However, the analysis of the filmic text reveals that the images have been shot in, practically, all the city's districts. This article explains how the quartier (neighborhood) has potentiated the cinematographic accent that it possesses and, equally, how the different components of the story grant the spectator several clues which, after being joined and structured, reveal a touristic guide which invite him/her to get lost in the complex reality of the city.
\end{abstract}

\title{
Keywords
}

Paris, Amélie, "ville lumière", neighborhood, Montmartre, 18ème.

Sumario: 1. París y el cine: repercusiones estratégicas. 2. Tras los pasos de Amélie: análisis fílmico y urbano de la película de Jeunet. 2.1. La presencia de lo icónico y lo emblemático. 2.2. Montmartre: el fabuloso destino de Amélie Poulain. 2.3. El escáner de una ciudad idealizada. 3. El destino de Amélie: de la cabeza a los pies de París. Conclusiones. 4. Bibliografía, videografía y webgrafía.

\section{París y el cine: repercusiones estratégicas}

Desde los orígenes del séptimo arte, la capital francesa no sólo ha hecho acto de presencia como ciudad representativa de su actividad comercial (se debe recordar que las primeras proyecciones de los hermanos Auguste y Louis Lumière tuvieron lugar en uno de sus bulevares centrales), si no, también y, sobre todo, como localización urbana principal. Un lienzo en el que se han desarrollado la gran parte de las producciones fílmicas francesas y, también, una mayoría de las norteamericanas que se han rodado en el marco europeo (con especial relevancia a partir de la segunda mitad de los años 50, cuando los decorados naturales empezaron a dominar), actualmente sigue atrayendo el interés de los creadores cinematográficos: según Mission cinéma, una iniciativa del Ayuntamiento parisino y que desde el 2002 persigue impulsar una política coherente y favorable para el mantenimiento de esta rama artística, 
cada año se ruedan en sus diferentes distritos alrededor de 800 producciones, siendo un número de 10 de media al día y una de cada dos de nacionalidad francesa. Pero, sus estudios también revelan otro dato llamativo y es que seis de cada 10 turistas amantes del séptimo arte reconocen visitar la denominada "ville lumière" por la influencia de sus creaciones.

Reconocido como una potente vía de explotación turística, el cine ha ocasionado la aparición de todo tipo de estrategias en París, tanto de carácter público como privado. Por citar algunos ejemplos, el mismo ayuntamiento ofrece parcours $^{1}$ (recorridos) que recogen, bajo el diseño de una pequeña guía, algunas de las localizaciones de películas de diferentes nacionalidades (con predominio de las galas) que se han rodado en sus inmediaciones: El diablo viste de Prada (David Frankel, 2006)², La invención de Hugo (Martin Scorsese, 2012), Midnight in Paris (Woody Allen, 2011), París (Cédric Klapisch, 2009) o Un monstre à Paris (Bibo Bergeron, 2011), son algunos de los títulos consultables. Sin embargo, esta medida, que ha tenido una repercusión notable (cada plano cuenta con una tirada de impresión de 5.000 ejemplares -20.000 para el caso de Ratatouille, de Brad Bird y Jan Pinkava, estrenada en 2007-, es bastante reciente (surgió en enero del último año citado), algo que Valérie Ganne, Julliard-Mourgues y Franck Priot explican de la siguiente manera (2009: 92):

Dada la ausencia de un estudio universitario profundo, nos arriesgamos con una explicación fundada en nuestra Historia del Arte. En la cultura francesa, el cine, en primer lugar, fue percibido como una prolongación de la fotografía. Además, sus inventores, los hermanos Lumière, eran fotógrafos en sus inicios, y su famosa película "La salida de las fábricas Lumière" ;muestra a los obreros saliendo de su fábrica de placas fotográficas! Esta herencia conceptualizada por algunos teóricos franceses como André Bazin o Henri Agel después de la Segunda Guerra Mundial tendió a hacernos considerar el rodaje de la imagen de una película como la captación de un momento de realidad, orquestado por el realizador, momento que el paso del tiempo hace desaparecer sin esperanza de que regrese $e^{3}$.

\footnotetext{
${ }^{1}$ http://www.paris.fr/loisirs/paris-et-le-cinema/parcours-cinema/rub_8358_stand_11911_port_19409

${ }^{2}$ Las películas aparecen referidas bajo el título castellano cuando se conoce la fecha de su estreno en España. En caso contrario, se citan con el nombre original y la fecha del país de producción.

${ }^{3}$ Traducción del original M. Tovar.
} 
El mismo principio de ofrecer de manera específica al lector-espectador las ubicaciones donde se han filmado escenas o planos de diferentes películas han seguido diversas publicaciones como Ciné Paris. 20 balades sur des lieux des tournages mythiques (Virginie Descure y Christophe Casazza. 2003. Hors Collection. París), Le Paris du cinéma. Guide illustré de la Ville Lumière. 800 adresses liées au septième art (Vincent Perez y Philippe Durant. 2011. Éditions Favre. Lausana y París) o Paris vu au cinéma. Le premier guide touristique dévoilant les lieux de tournage de 300 films de référence (Marie-Christine Vincent y François de Saint-Exypéry. 2006. Movie Planet. París), entre otras.

Conscientes, también, de la repercusión positiva que podrían tener sus presencias en los textos fílmicos, muchos de los Monumentos Nacionales y museos parisinos decidieron, a partir del 2006, conceder permisos a los equipos cinematográficos que lo desearan para que trabajaran en sus interiores $\mathrm{o}$, incluso, desarrollaron programas que buscaban, esencialmente, esa manifestación, proyección del elemento arquitectónico, histórico y cultural, como el Musée du Louvre con Le Louvre s'offre aux cinéastes (un concurso en el que se seleccionaron los tres mejores guiones que desarrollaban la mayor parte de su contenido en las entrañas de una de las instituciones más emblemáticas de la "ville lumière") y el Musée d'Orsay con una propuesta en la que invitó a cuatro cineastas contemporáneos a rodar cortometrajes en los que la antigua estación de trenes debía aparecer, al menos, en uno de sus planos.

Lo que se evidencia con estas breves referencias es que la ciudad de París es consciente no sólo de la proyección que su imagen tiene en todo el mundo gracias a la producción y consecuente consumo de materiales cinematográficos; sino también, de cómo esto puede ser potenciado en su propio beneficio a diferentes niveles y de cómo puede ofrecer al espectador diferentes medios para que la realidad de la película se convierta en otra tangible, palpable, habitable.

Se llega, de esta manera, al caso de la película que protagoniza este trabajo. Estrenada, como se indica en las primeras líneas, en el año 2001 y con un total de 23 millones de espectadores en todo el mundo (nueve en el mercado francés), Amélie es uno de los títulos clave para la concepción cinematográfica de la capital francesa, pero, en cierta medida, limitada a un barrio concreto, como comentan Ganne, Julliard-Mourgues y Priot (2009: 95-96): 
El realizador reinventó su barrio de Montmartre, pero, rodaron en dos localizaciones reales: el café donde trabaja Amélie Poulain," Les deux moulins", y la tienda (de ultramarinos) Collignon. Desde hace ocho años, estos dos lugares son regularmente visitados por los turistas, tanto de Francia como del extranjero. Algunas guías turísticas mencionan este paseo y el Sindicato de Iniciativa de Montmatre ha creado un circuito 'Tras los pasos de Amélie Poulain' todavía más demandado. Los turistas son, sobretodo, anglosajones. La película, conocida en el extranjero bajo el título "Amélie de Montmartre", ha conquistado casi seis millones de espectadores en Estados Unidos y un millón en Gran Bretaña. Pero, los japoneses (también un millón de espectadores) son igualmente unos apasionados de la guapa Amélie y acuden a "Les deux moulins" para comerse una crème brûlée 4 .

Se encuentra, de esta manera, en esta cita varias de las ideas que van a protagonizar los siguientes epígrafes y que, igualmente, serán tratadas en mayor profundidad: si bien se reconoce el protagonismo residente en el barrio de Montmartre, ya se ha explicado cómo, realmente, la película participa de otros arrondissements (distritos) de la capital gala; asimismo, el circuito del Sindicato va a ser analizado con bastante detenimiento y complementado con fotografías que revelan el estado actual de las localizaciones que lo configuran; y todo ello teniendo en cuenta esos detalles que se referían en el resumen y por los que se postula que, realmente, Amélie es más que una producción fílmica llegando a erigirse como una guía turística, en cierta manera, reduccionista, de la "ville lumière".

\section{Tras los pasos de Amélie: análisis fílmico-urbano de la película de Jeunet}

\subsection{La presencia de lo icónico y lo emblemático}

Los primeros minutos de cualquier largometraje son esenciales para el espectador de cara a la ubicación geográfica del relato al que se enfrenta, entre otros aspectos. De esta manera, muchos autores han denunciado la aplicación de un cierto estereotipo que conlleva que, cuando la acción se desarrolla en ciudades de cierta relevancia, reconocibles o de fácil emplazamiento, se acuda a sus referentes icónicos o emblemáticos para presentarla. En el caso de París se reconoce una cierta alternancia, ya que, junto a la Tour Eiffel, aparecen el

\footnotetext{
${ }^{4}$ Traducción del original M. Tovar.
} 
Arc de Triomphe, Notre-Dame, el Sacré-Cœur o el río Sena. Incluso, en numerosos casos (entre ellos, por ejemplo, una de las secuencias iniciales de Una cara con ángel -Stanley Donen, 1961-), estos elementos conviven en los mismos planos o en otros alternos o continuados, como explica Thierry Flamand en Visions urbaines. Villes d'Europe à l'écran (1994: 8):

Una simple frase en el guión: 'La acción se desarrolla en París (Roma, HongKong o Nueva York)' se traduce en pantalla por una sobreimpresión, algunas veces con una fecha sobre una vista general, del tipo de las que se compran en diapositivas en los aeropuertos... En el momento de dejar el país. Es la especialidad de las películas de aventuras (...). En este tipo de producciones, la ciudad aparece mostrada al azar en tomas exteriores, ejerciendo su función de 'postal'. Exótica para el espectador extranjero, familiar para el autóctono 5 .

Si bien en el caso de Amélie hay que esperar a que la acción esté bastante desarrollada para encontrar una de esas famosas vistas generales de la ciudad, no ocurre lo mismo con sus reconocidos iconos. En este sentido, Alain Servel, a finales de los años 80, explicaba en su libro Frenchie goes to Hollywood. La France et les français dans le cinéma américain de 1929 à nos jours que la Tour Eiffel ya se había constituido, en el caso de las producciones norteamericanas, como un elemento indicativo fundamental y cuya presencia en sus primeros minutos era prácticamente obligatoria para que el espectador pudiera fijar el decorado urbano que soportaría el desarrollo narrativo sin ningún tipo de ambigüedad.

Esto también se puede aplicar aplicable al caso de las películas francesas, si bien, su propia historia cinematográfica ha determinado que su tratamiento visual haya sido variable según los parámetros característicos de las diferentes etapas que la constituyen. Con esto, lo que se quiere decir es que, independientemente de la nacionalidad de la producción, cuando un texto fílmico se desarrolla en París, siempre aparece durante los minutos iniciales un referente emblemático que, como defendía Servel, permite la identificación del elemento urbano, pero, igualmente, ancla al espectador a ese espacio sumergiéndole en una metrópoli concreta y en la que se va a ir adentrando progresivamente.

${ }^{5}$ Traducción del original M. Tovar. 
De este modo, lo que se descubre en los primeros diez minutos de Amélie es una secuencia de elementos icónicos que permite reconocer a la "ville lumière" como lienzo pasivo ${ }^{6}$ principal: después de ubicar el primer plano en el

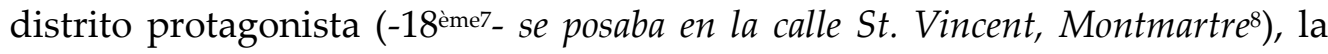
cámara se traslada a un restaurante que, como indica la voz del narrador, se encuentra cerca del Moulin de la Galette (el otro gran molino del 18 ème, ubicado en la Rue Lepic) y desde donde se identifica al icono parisino por excelencia: la Tour Eiffel (7ème). El siguiente plano tomado, según esa voz externa, desde la Avenue Trudaine, en el vecino 9ème, muestra a otro de los referentes emblemáticos de la capital gala: el Sacré-Cœur (18ème). Así, en menos de un minuto, el espectador ya se ha ubicado en un distrito específico (el $18^{\mathrm{ème}}$, dada la abundancia de imágenes filmadas en él) y, al mismo tiempo, ha reconocido y determinado la ciudad en la que viven los personajes: París.

Sin embargo, se produce un mayor afianzamiento de estos datos pocos minutos después cuando, de nuevo, el narrador cuenta cómo murió la madre de Amélie, obligando a la cámara a ubicarse frente a la fachada principal de la catedral de Notre-Dame (4 $\left.{ }^{\text {ème}}\right)$ y cuando informa de la actividad como camarera de la protagonista en un bar de Montmartre llamado Les deux moulins. Se aprecia una cierta función conclusiva en esta última secuencia y es que estos primeros minutos contextualizan el relato; es decir, dan al espectador, como se ha defendido, las claves para que ubique espacialmente el relato, pero, también, presentan a los personajes concediéndole el acceso a los mismos y, en cierta forma, forzando su integración en el texto fílmico. Se trata, por tanto, de un fragmento introductorio acotado por una referencia espacial, Montmartre, que, como se ha comentado, es un definidor capital para la historia firmada por Jeunet.

\footnotetext{
${ }^{6}$ El concepto lienzo pasivo se emplea en este trabajo bajo la consideración de que la ciudad es un gran decorado sobre el que van a deambular los diferentes personajes, siendo sus acciones y sus movimientos los que determinen el desarrollo narrativo. En cierta medida, es un término cercano al de no lugar de Augé, ya que, el espacio, en sí mismo, no les afecta de manera alguna. 7 Para continuar el modelo aplicado en los documentos franceses, los elementos urbanos citados serán referidos de acuerdo al sistema de los arrondissements (distritos). De esta manera, a partir de ahora se citarán según la forma "n ème", siendo "n" el número del mismo.

${ }^{8}$ Las referencias textuales extraídas del DVD de la película -cuya información aparece en la bibliografía- corresponden a los subtítulos en castellano de la edición consultada.
} 
2.2. Montmartre: el fabuloso destino de Amélie Poulain.

Como se indica al principio, el Sindicato de Iniciativa de Montmartre ofrece la posibilidad de recorrer el barrio de Amélie según las directrices cinematográficas que constituyen el plano que puede adquirirse en la oficina que tiene en la Place du Tertre. Redactado en diversos idiomas, su edición francesa comienza de la siguiente manera:

Usted también, viva su fabuloso destino.

¡Bienvenido a Montmartre! Como a millones de personas, le ha gustado Amélie, quien, después de su estreno francés en 2001, ha dado la vuelta al mundo. En la primavera de 2000, Jean-Pierre Jeunet y sus actores rodaron en nuestro barrio que le invitamos a conocer tras los pasos de Amélie... (trad. del original M. Tovar).

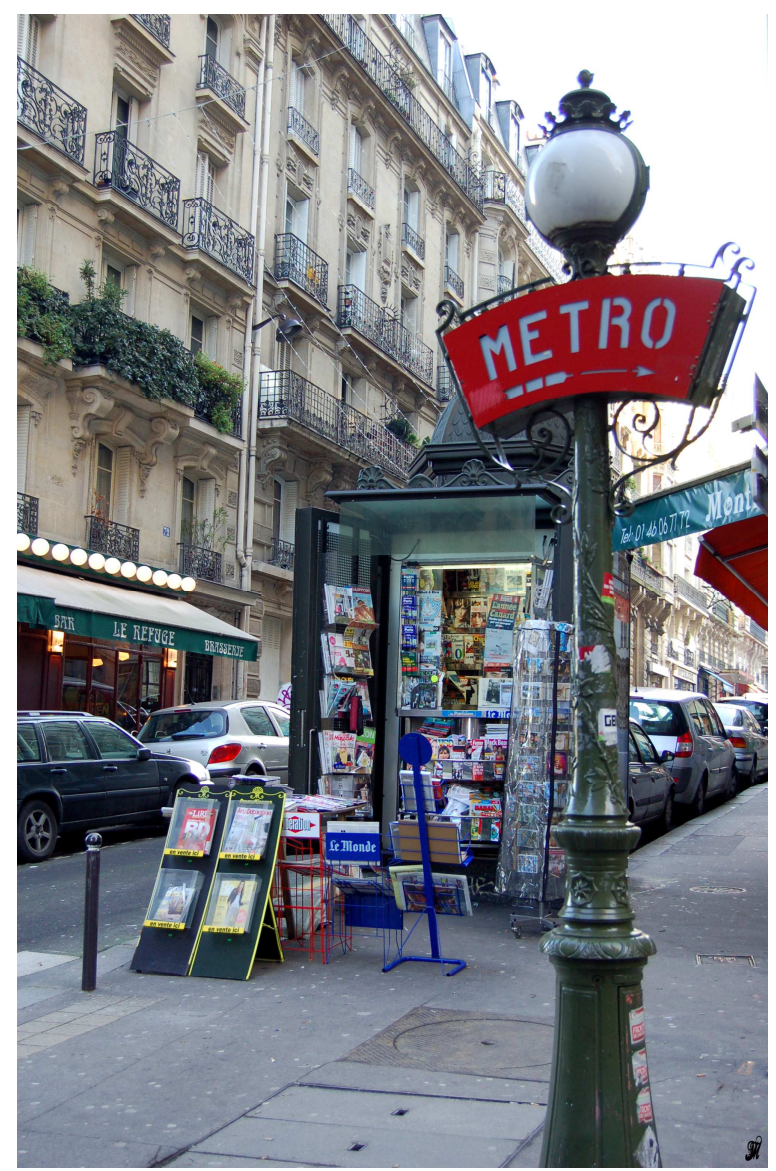

Fig. 1. Kiosko y entrada del metro. (C) Foto Mónica Tovar 
Iniciando el recorrido en esa plaza, la siguiente indicación invita al visitante a trasladarse a la calle que inaugura el relato cinematográfico: la rue Saint Vincent [00:30]. Comenzando en la parte posterior del Sacré-Cœur, esta calle empedrada y que mantiene, así, unos de los rasgos de la butte es también lugar de interés para muchos melómanos que saben que fue allí donde vivió durante dos años el compositor Héctor Berlioz. Continuando el paseo, la siguiente localización es la estación de metro de Lamarck-Caulaincourt, lugar donde Amélie deja al invidente después de haberle ayudado a cruzar la calle [35:14]: Ahora estamos en el kiosko, delante del metro. Aquí lo dejo. Hasta luego. Sin embargo, la calle que se muestra no corresponde a la misma donde se encuentra esa parada de metro: la que recorren los personajes es la rue Lepic, la misma donde se encuentra Les deux moulins y que, sin embargo, nunca es citada cuando el establecimiento aparece en pantalla. Caracterizada por una importante actividad comercial (en sus aceras hay una pescadería, una carnicería, una quesería, bares y servicios hosteleros de diferentes características), fue uno de los mayores retos a los que se enfrentó Jean-Pierre Jeunet cuando inició el rodaje, ya que tuvo que respetar ciertas condiciones impuestas por la Asociación de Comerciantes de la zona como fueron la ausencia de cables por las aceras o la imposibilidad de rodar los fines de semana o durante el período de expedición de las mercancías (Pérez - Durant, 2011: 294).

El siguiente punto del recorrido es, con bastante probabilidad, uno de los que habitualmente no sería visitado por los turistas, a pesar de la escasa distancia que lo separa del Sacré-Cœur. Escondido en el passage Cottin y al que se desciende por unas estrechas escaleras, se encuentra el muro en el que, al final del relato [1:50:26], aparece escrita una de las frases de Hipólito (Sin ti, las emociones de hoy serían solo la piel muerta de las pasadas), el fracasado escritor asiduo al bar.

En este sentido, se considera más que llamativa esta inclusión en el recorrido, ya que, de hecho, el personaje no es tampoco uno de los más determinantes para el relato. De este modo, y como se ha propuesto anteriormente, se considera que el Sindicato ha aprovechado su presencia para invitar al turista

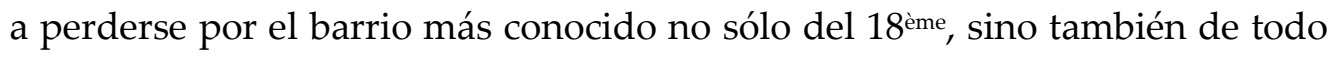
París; es decir, que se introduzca en las entrañas del arrondissement accediendo así a otros lugares que, aunque no aparezcan como tales, también podrían haber sido localizaciones de la película. Y es que se ha de tener presente que, 
aunque el documento se ha editado con el objetivo de satisfacer el interés de recorrer el Montmartre de Amélie, también ha encontrado en tal acción la posibilidad de dar a conocer una zona que habitualmente es transitada de manera puntual, regida por aquellos iconos que la habitan.

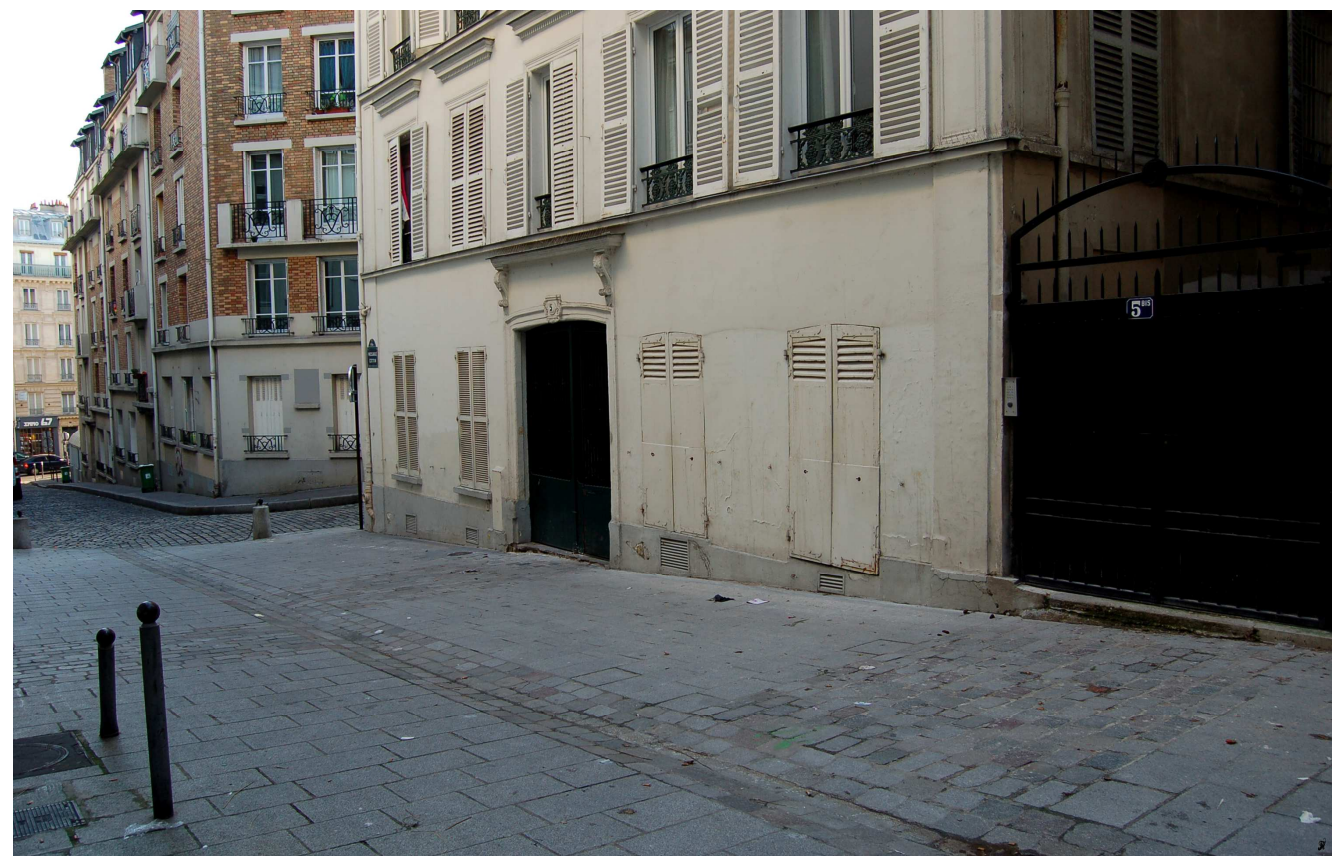

Fig. 2. Estado actual de la pared. Passage Cottin. @ Foto Mónica Tovar

De ese espacio posiblemente sólo conocido para los habitantes del barrio se pasa a otro de los más visitados: le square (parque) Louise-Michel, también conocido como la plaza del Sacré-Cœur, y donde, además de zonas ajardinadas, se encuentran las escaleras que constituyen uno de los accesos a la basílica. Es precisamente a los pies de esos escalones donde se encuentra el tiovivo en el que se produce uno de los encuentros entre la camarera y su compañero protagonista [1:10:37].

El sexto punto del recorrido es uno de los espacios que mayor trascendencia tiene para la rutina diaria de Amélie: la tienda de Collignon y que, realmente, se encuentra en el cruce de la rue des Trois Frères con la de Androuet. En relación con este lugar, el director de la película explica en los comentarios de la misma incluidos en la edición consultada que [18:38]: 
No es un mate painting, no hay más trucaje que el cielo. Es una verdadera localización, sólo modificamos la verdulería. Hoy está tal cual. Se ha convertido en una magnífica y fina verdulería y antes era un poco 'cheap'. La vida del verdulero ha cambiado, la verdulería es bonita... Y él hace exposiciones de foto. La vida del barrio ha cambiado. Me agradecen que haya cambiado el barrio. Hace mucha ilusión cuando el cine interviene en la vida de la gente.

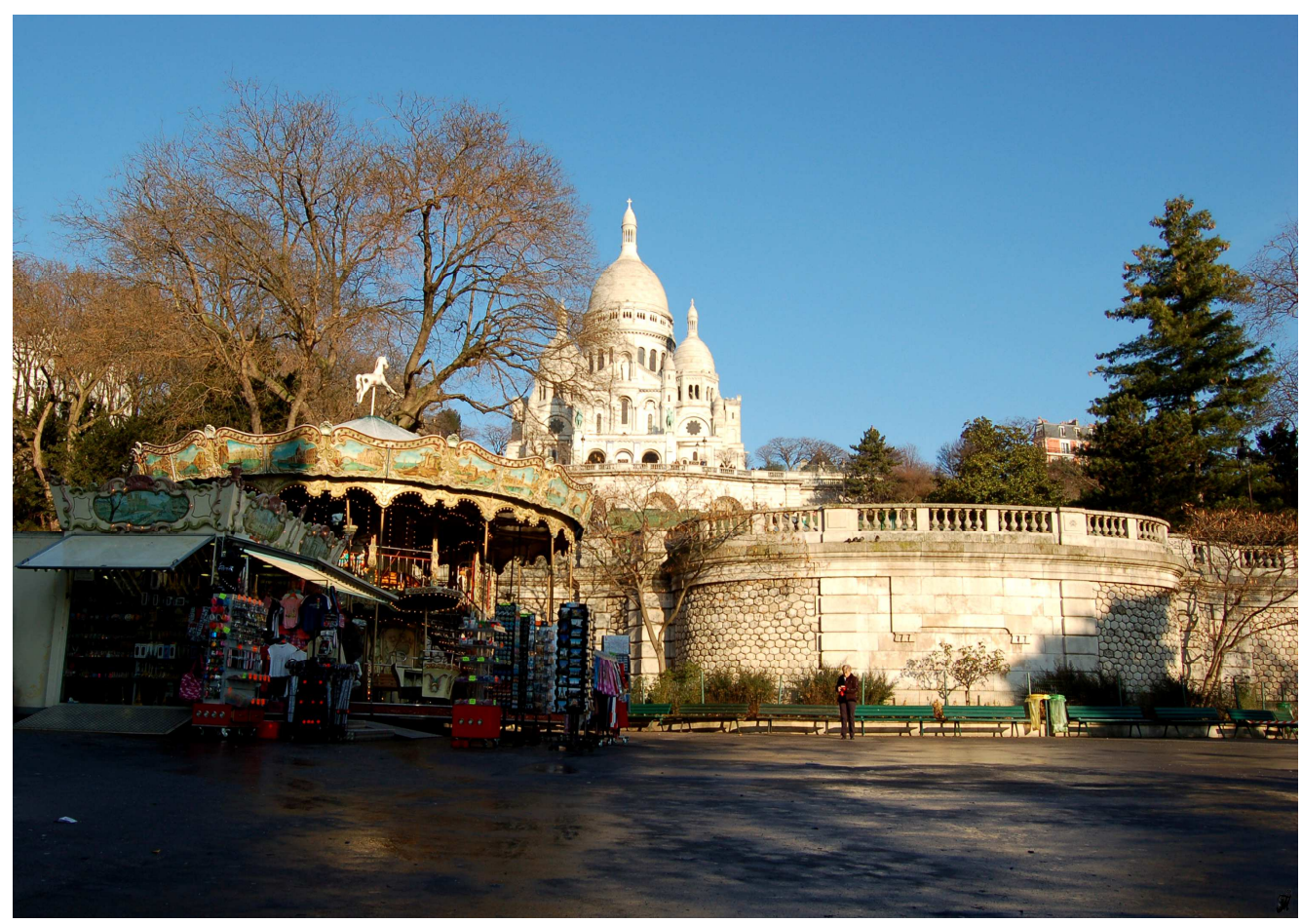

Fig. 3. Tiovivo de le Square Louise-Michel con el Sacré-Cour de fondo y sin la cabina de la película. (C) Foto Mónica Tovar

Si bien ya se vienen enunciando algunos de los efectos que el estreno de Amélie tiene y mantiene para Montmartre y París, posteriormente se profundizará con mayor detenimiento en los mismos. Lo que interesa de la cita incluida es, sobre todo, la repercusión directa que tuvo el rodaje para la tienda: si, como indica Jeunet, ha sufrido un cambio de estilo, también es notable el agradecimiento que su dueño manifiesta a la producción cinematográfica. Como se aprecia en la fotografía (Fig. 4), a los productos habituales de este tipo de establecimiento se suman postales y pósters de la película, mientras que el ventanal que aparece en el 
lado izquierdo, y que se descubre si se continúa andando por la rue des Trois Frères, muestra recortes de noticias aparecidas en la prensa gala.

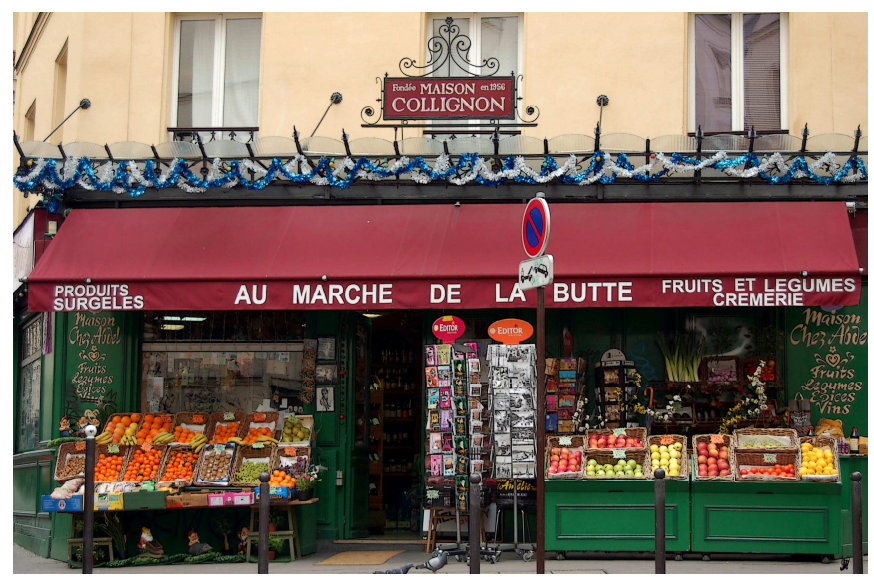

Fig. 4.

Tienda del personaje Collignon en la actualidad.

(C) Foto Mónica Tovar

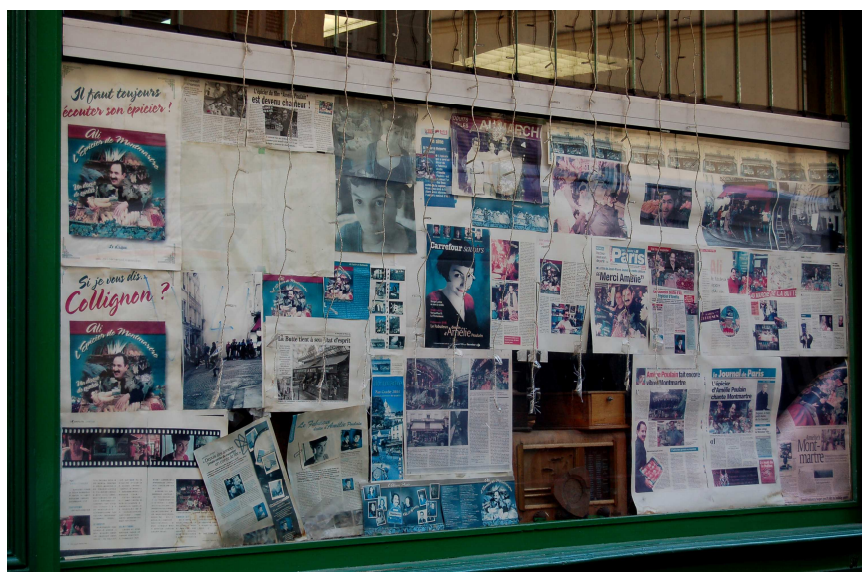

Fig. 5. Ventanal de la tienda con recortes de prensa

(C) Foto Mónica Tovar

El último punto cinematográfico recogido en el recorrido ofrecido por el Sindicato es el bar en el que trabaja la protagonista; actualmente, una de las localizaciones de la película más visitadas, como explica el realizador [24:06]:

El café "Les deux moulins" a 100 metros de mi casa en Montmartre. La primera vez que lo vi, pensé: 'Aquí rodaré. Interrogué a la hija de los dueños, que es un poco actriz. Le pregunté si habían rodado allí y me dijo: 'Sí, pero nunca más'. Tardé un año en persuadirlos poco a poco. Hoy están felices, el café siem- 
pre está lleno y la gente viene a verlo. Preguntan dónde están el cristal o el neón, pero, formaban parte del decorado. Quieren ver rostros del rodaje. Ahora lo comprarán o lo fabricarán porque se ha convertido en un sitio turístico.

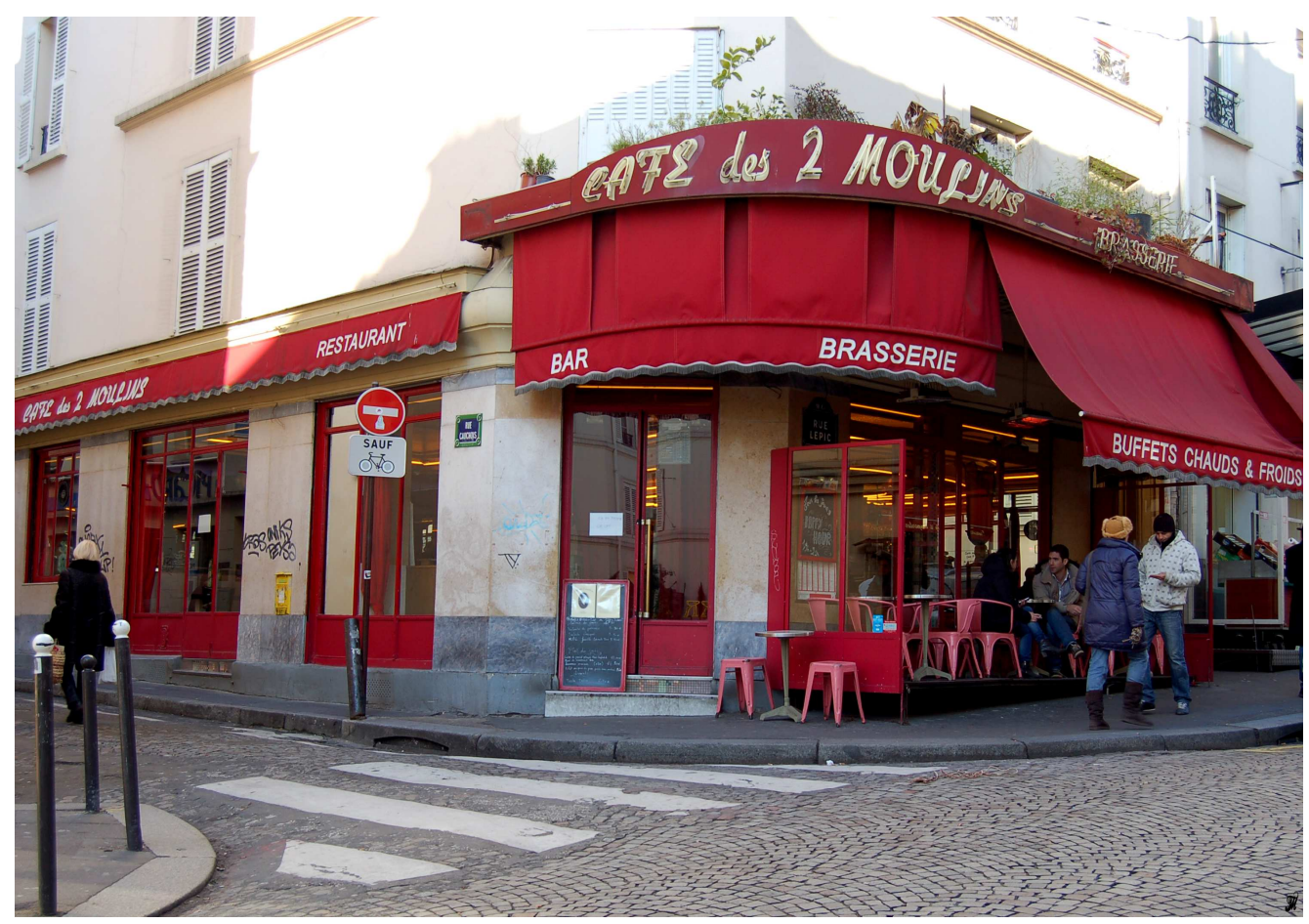

Fig. 6. Café "Les deux meulins" en la actualidad. OFoto Mónica Tovar

Si anteriormente se indicaba cómo el dueño de la tienda de Collignon mantenía la presencia de Amélie con la oferta de diversos productos y la muestra de los recortes de prensa, en el caso del bar las reminiscencias de la película son aún más notables al encontrarse un cartel de la producción en una de sus paredes y al haber convertido a la camarera en la protagonista de su carta y de los manteles individuales que cubren las mesas y que, a día de hoy, pueden ser adquiridos por los comensales después de su visita al recinto.

Se aprecia, por tanto, una adopción de los elementos del universo fílmico por parte de los vecinos del arrondissement e, igualmente, por aquellos que participaron de manera activa en la producción al permitir que sus comercios se convirtieran en decorados; sin olvidar al propio Sindicato que, como se ha 
explicado, continúa explotando turística y, al mismo tiempo, económicamente el recuerdo perdurable del personaje creado por Jeunet. Sin embargo, en este sentido, surge la consideración, ya presentada a partir de las palabras del realizador, de la búsqueda que el turista, el apasionado de la película realiza de todos aquellos referentes que la caracterizan (Ganne, Julliard, Priot, (2009: 58):

El medio audiovisual consume muchos paisajes bonitos y las imágenes de las películas pueden constituir un medio concreto y objetivo para descubrir decorados que nos eran desconocidos hasta entonces. La ficción fascina, a través de la posibilidad que nos ofrece de identificarnos con sus héroes y 'de atravesar mundos más cercanos a nuestros deseos que a la realidad' (por parafrasear a François Truffaut). Ahora bien, una parte esencial de nuestro consumo de ficción se hace a través del medio audiovisual -cine y televisión-, siendo ahí donde nacen nuestros héroes. El hecho de encontrar los decorados de las películas nos permite volver a penetrar en sus mundos, pasar, en cierta medida, al otro lado del espejo y acercarnos a ellos. La influencia de las películas y "to movies" se inscribe también en los fenómenos de culto a las celebridades. Encontrar en las localizaciones los restos del paso de las estrellas es compartir un poco su intimidad y tener una experiencia compartida con ellas (trad. del original M. Tovar).

Por tanto, el espectador, con la realización de ese parcours, con la repetición de los pasos que da Amélie por Montmartre, lo que consigue es adentrarse personalmente, físicamente en ese relato ficcional al que previamente también ha pertenecido, ya que, como se ha defendido, el texto está construido de tal manera que desde los primeros minutos persigue la participación activa del receptor del mismo que, de una manera u otra, acaba siendo un personaje más. Pero, ese deseo de revivir el destino de la protagonista, eje principal de la narración, le traslada a otros puntos de la "ville lumière" surgiendo, así, esa pequeña guía turística que se enuncia en las primeras líneas y que, al mismo tiempo, revela que Amélie de Montmartre no es un relato únicamente del 18 ème.

\subsection{El escáner de una ciudad idealizada}

Si se observa con detenimiento la evolución histórica de la cinematografía gala se descubre que, desde sus orígenes, se ha caracterizado por la convivencia de dos grandes modelos: el documentalista-realista introducido por los hermanos Lumière y el ficcional heredero de Georges Méliès. Una dualidad 
que se ha mantenido a lo largo de las décadas, si bien, sujeta a normas y patrones narrativos y de género variados y que, desde los inicios del siglo XXI, ha encontrado en Jean-Pierre Jeunet a uno de los representantes esenciales del segundo esquema. Frente a él, Cédric Klapisch, cineasta que, aunque como él trabaja en el ámbito de la ficción, potencia de manera evidente el carácter social adoptando ciertas marcas documentalistas en sus narraciones.

El tratamiento estético, gran característica de Amélie y uno de sus potenciales diferenciadores (tanto a nivel de la producción francesa de la época como del universo creativo de su autor), le muestra al espectador un París de postal, idealizado, como el mismo Jeunet señala en los comentarios de la película (cfr. [57:23]); un tratamiento que recuerda, en cierta manera y de forma concreta, a las películas galas de los años 20 y 30 y entre las que Paris qui dort (René Clair, 1923) destaca como representante. Pero, el largometraje también toma referencias de otros nombres ligados a la identidad contemporánea de la urbe, como explica el realizador [1:29:57]:

El París estilo Tardi', me lo han dicho mucho. Me gustan sus cómics. A los dos nos gusta París con sus puentes de piedra y metal (...). Todo este París con los metros aéreos. Es un París muy Eiffel, muy particular en el que pasé mucho tiempo con las localizaciones. Dos asistentes se recorrieron todo París y las afueras haciendo fotos. Hemos pasado mucho tiempo para cada pequeño decorado.

Esas localizaciones son, como se viene señalando, esenciales, ya que permiten reconstituir a la capital francesa, prácticamente, en su totalidad y es que, como se explica en las siguientes líneas y en las que se va a continuar el desarrollo cronológico del texto fílmico, cada uno de esos espacios pertenece a un distrito diferente.

Después de los primeros minutos de la película, ya reconocidos como estereotípicos en cuanto que presentan a varios de los iconos de la metrópoli, la cámara se traslada a la Gare du Nord (10 ème), tal y como narra la voz en off en la versión original [10:57]. Principal estación de la parte norte de la ciudad, como su nombre indica, sus trenes la conectan con la banlieue, poblaciones y comunas que la rodean por esa área y con los países limítrofes (Alemania, Bélgica, Gran Bretaña y los Países Bajos). El siguiente elemento reconocible

${ }^{9}$ La persona a la que se refiere Jean-Pierre Jeunet es Jacques Tardi, ilustrador de comics francés. 
que aparece en la cinta, igualmente presentado por el narrador [12:15], es el canal Saint-Martin ubicado en el mismo arrondissement (10). Es llamativa, en este caso, la naturaleza del plano que juega con los ángulos y las alturas concediendo al espectador una imagen que, por el contrario, es prácticamente imposible de lograr cuando se visita la localización y se desea fotografiar el posible lugar filmado.

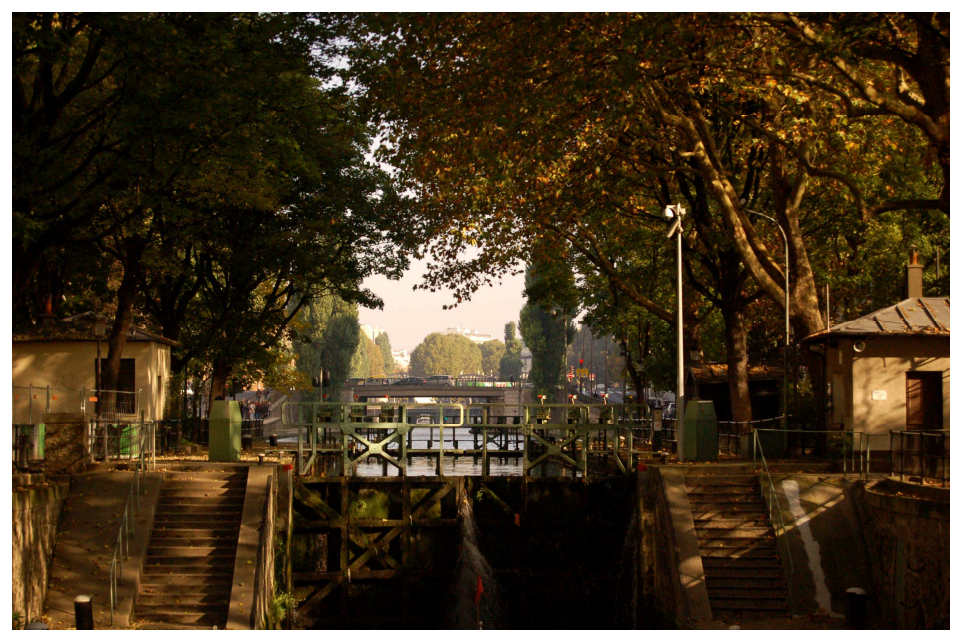

Fig. 7. Una de las exclusas del canal. (C) Foto Mónica Tovar

Precisamente, este detalle es notable en las guías fílmico-turísticas consultadas y es que en ninguna de ellas se determina el punto exacto del rodaje. Dada la longitud del canal (próxima a los cinco kilómetros) es bastante complejo determinar la calle o el cruce en el que se encuentra la exclusa sobre la que se presenta a Amélie. Lo que se deriva de este aspecto es que, como ocurre con el recorrido del Sindicato y con la mayoría de los otros parcours, aunque se detallan algunas de las localizaciones, su búsqueda y visita implican el acceso, el paso por otros puntos de la urbe.

La cámara regresa, supuesta y posteriormente, al barrio de Amélie al presentarla en la parada de metro de Abbesses, ubicada en la plaza del mismo nombre. Aunque la estación presenta en sus tradicionales paredes de ladrillo blanco ese nombre [21:26], realmente, la secuencia fue filmada en otra parada de la red de metro parisino: la de Porte des Lilas, entre el 19 y el 20 ème. Se produce, así, un desplazamiento de la cámara sobre el plano de la ciudad que, siempre en la zona norte, después de haber comenzado el relato en el centro, 
se desplaza hacia la derecha pasando, primero, por el 10 ème, como se ha indicado, y llegando ahora a esta otra zona que conecta, directamente, con la banlieue. La ausencia de correspondencia entre lo filmado y la realidad en la que se inspira queda justificada por una medida de la RATP (Régie autonome des transports parisiens -Compañía arrendataria autónoma de los transportes parisinos-), encargada de conceder los permisos de rodaje en sus instalaciones y que suele ofrecer a los cineastas la indicada estación, tanto por contar con los dispositivos necesarios, como por tratarse de una parada con un menor número de usuarios que las de las principales zonas centrales y turísticas; reduciendo, así, el número de posibles molestias a los mismos.

Poco tiempo después se presenta un plano que, dadas las características de uno de los elementos que lo constituyen, le informa al espectador de que, posiblemente, la joven camarera se encuentra lejos de su distrito original, ya que, detrás de ella se presentan las vías de una de las líneas de metro aéreo de la ciudad [25:41]. Asimismo, el hecho de que, poco después, la cámara se pose sobre la agenda que lleva y recoja cómo tacha una dirección del 1 ${ }^{\mathrm{e}}$, confirma su efectivo desplazamiento. Sin embargo, todos estos detalles revelan el engaño de la localización por los siguientes motivos: en primer lugar, si bien la calle en la que, supuestamente, se encuentra (rue du Colonel Driant) pertenece al primer arrondissement, los metros que pasan por las áreas más próximas (líneas 1 y 4), son todos subterráneos. En segundo, si se reduce el plano del metro a las líneas que presentan la condición de aéreas en alguna de sus estaciones, se descubre que, únicamente, son la 2 (Porte Dauphine - Nation), que recorre los distritos 16,17-810,18-9, 10, 19 y 20-12; y la 6 (Charles de GaulleÉtoile - Nation), que tiene repartidas sus paradas por el sur de la capital (16, $15,14,13$ y $\left.12-20^{\text {èmes}}\right)$. Si se combinan los trazados de ambas se descubre que, efectivamente, comparten una de sus estaciones terminus, pero, igualmente, que constituyen un círculo que rodea la parte "exterior" de la "ville lumière"; es decir, son las dos líneas de metro principales que se crearon para conectar las comunas que se integraron en el trazado urbano de la capital a finales del siglo XIX. En tercer lugar y una vez reducidas las posibles opciones, primeramente, se postula la idea de que, dado que Amélie reside en Montmartre y

\footnotetext{
${ }^{10}$ Dado que algunas de las estaciones de metro se encuentran en la frontera de dos arrondissements vecinos, se les cita de manera conjunta.
} 
la línea 2 presenta estaciones próximas a algunas de las localizaciones (Blanche -la rue Lepic, además del Moulin Rouge-, Pigalle -conexión directa con la Place des Abbesses a partir de una calle- y Anvers -Sacré-Cœur-), esta escena podría haberse filmado en alguna de ellas; pero, ninguna cumple con la condición de aérea. Posteriormente, y después de haber consultado las guías fílmico-turísticas, se descubre que otra de las escenas de la película (aquella en la que Nino pone carteles pidiendo a la extraña del fotomatón que se encuentre con él) fue rodada en la estación de La Motte-Picquet-Grenelle (línea 6) en el 15 ème (Perez y Durant, 2011: 243). Tras comprobar el diseño de este espacio que, sin embargo, comparte detalles con otras paradas de la misma línea, se ha considerado que, dada la lógica productiva de aprovechar las localizaciones para rodar en ellas todas las escenas que sean posibles con el objetivo de reducir costes, lo más posible es que, efectivamente, y dadas las características de la imagen que no concede demasiados elementos que faciliten la ubicación específica del lugar, se trate de esta parada que cuenta con accesos en las calles du Commerce y de Pondichéry, el bulevar de Grenelle y las avenidas de la Motte-Picquet y de Suffren.

Regresando a la agenda que se mencionaba en líneas anteriores, en ella aparecen escritas otras dos direcciones que presentan, de esa manera, a los decorados que se suceden después en el montaje. El primero de estos lugares se ubica en el número 6 de la rue Jasmin (16 $\left.{ }^{\text {ème}}\right)$ y, efectivamente, realidad y ficción coinciden. De este caso destacan, sobre todo, dos aspectos: el primero es que, antes de llegar a la vivienda, las imágenes muestran a Amélie en el interior de un metro que, posteriormente, aparece recorriendo unas vías aéreas que son las que sobrevuelan el pont Bir-Hakeim (15 y $\left.16^{\text {ème }}\right)$, reconocible tanto por las características de la estructura que las sostiene como por la escultura ecuestre que señala al río Sena [25:49]. Reside, así, en este momento un pequeño y evidente guiño cinematográfico de Jeunet a la imagen fílmica de la capital gala, ya que, es en este mismo lugar donde se desarrolla una de las primeras escenas de El último tango en París (Bernardo Bertolucci, 1978). Pero, sobre todo, lo que interesa de esta presencia es que afianza la teoría de que, efectivamente, la escena precedente y que se había ubicado en las inmediaciones de la parada de metro La Motte-Picquet-Grenelle, se ha rodado allí. Se aprecia la lógica de la continuidad del personaje por el marco urbano $y$, al mismo tiempo, esa propia de la producción ya comentada. El segundo aspec- 
to que llama la atención es que la incursión de la cámara en este distrito parisino le permite al espectador acceder a un diseño arquitectónico y de viviendas diferente al imperante en la butte Montmartre: los tradicionales edificios parisinos caracterizados por sus fachadas y paredes en tonos beiges y sus techos de pizarra azul-grisácea, y que pueden apreciarse brevemente en este plano, encuentran en este distrito (uno de los habitados por las clases sociales de mayor poder económico y social) una de las mejores zonas de la ciudad para hacer gala de sus típicas ornamentaciones naturalistas que, además de apreciarse en las entradas principales (como en este caso [25:52]), también lo hacen en ventanas, terrazas y todos aquellos puntos visibles para los viandantes. La última dirección que aparece anotada en la libreta de la camarera protagonista se encuentra en el $15^{\text {ème }}$ al ser el número 5 de la rue Léon Lhermitte. Movimiento regresivo en el plano de la ciudad, ya que, del límite entre los distritos 15 y 16 se vuelve al primero, donde también se ubica La MottePicquet-Grenelle.

Aunque, a priori, este pequeño fragmento parece no tener gran importancia, su análisis revela una serie de ideas potencialmente importantes para este trabajo. La primera de ellas es que, como se ha postulado más arriba, en Amélie el deseo de cumplir el objetivo que ella misma se ha marcado (primero, devolver la caja infantil a su dueño -búsqueda del propietario que se realiza en este momento del desarrollo narrativo- y secundaria y consecuentemente, hacer feliz a los demás) implica que salga de la zona urbana con la que se la ha identificado. Como se explica en líneas posteriores, esa visita de la ciudad que se ha iniciado con estos primeros traslados tiene continuidad en las siguientes secuencias. La segunda idea, relacionada con esta, conlleva la aplicación de las teorías de autores como Propp, Greimas o Lévi-Strauss y que abordan la figura del personaje en relación con los otros elementos del relato. Brevemente, para el caso del largometraje de Jeunet, si se aplica el esquema greimasiano, Amélie, quien ejerce como sujeto o personaje principal, ostenta la capacidad de hacer feliz a los demás como demuestra con su primera actuación al remitirle la caja a su dueño y comprobar la emoción despertada en este. Su prueba decisiva se presenta poco después cuando se encuentra con el álbum de fotos perteneciente a Nino, siendo su nuevo objetivo la devolución del mismo. Sin embargo, la realización de esa prueba se encuentra con diversos elementos que ejercen cierta oposición a su consecución y que encuentran 
en la propia camarera y, sobre todo, en sus sentimientos, la principal barrera. Al mismo tiempo, la figura del hombre de cristal, su vecino, actúa como cierto revulsivo para la resolución definitiva del deseo: Amélie, ya convertida en heroína al dejar en manos de Nino lo que era de su propiedad, ha de aceptar la realidad que le liga a ese otro personaje dejando que este acceda a ella y permitiéndole que cierre tanto su historia propia como la que constituye todo el texto fílmico. Ahora bien, lo que interesa de esta estructura narrativa que, en cierta manera, es bastante compleja dada la presencia de diversos actantes y el establecimiento de conectores de diferentes características entre ellos, es que es esa búsqueda de la consecución del objetivo, la realización del deseo la que explica y justifica el traslado de la cámara por la mayoría de los distritos de la capital francesa.

La última idea nacida del estudio de este fragmento y que ha de ser comentada remite, precisamente, a esas localizaciones parisinas que se alejan de la zona principal, de Montmartre. Como se ha comentado en este caso, el realizador le da al espectador información concreta: ya sea a través de la voz del narrador o de recursos reales y del decorado (el indicador de la estación de metro de Abbesses, la libreta), el destinatario del largometraje siempre sabe a dónde ha de dirigirse para encontrar esos espacios que, como se ha explicado anteriormente, es una de las vías que tiene para que esa ficción que ha consumido se convierta, temporalmente, en realidad. Pero, estos apuntes también implican el acceso a la ciudad: ya se ha defendido que, con la publicación de los parcours y de los diferentes recursos, el espectador no sólo visita lo que forma parte del relato, también, lo que le rodea, aumentándose ese consumo de lo arquitectónico, lo urbano y favoreciéndose el acceso al mismo implicando, igualmente, ciertas connotaciones turísticas y, por extensión, económicas, otro de los grandes objetivos que justifican este tipo de iniciativas. Sin embargo, y como se aborda más abajo, no siempre se cumple de manera absoluta con el deseo del turista-espectador al desconocerse las ubicaciones de ciertas localizaciones o al existir grandes diferencias entre lo mostrado y lo real en lo que se inspira y que impiden su reconocimiento.

La fase final de la búsqueda de Bretodeau y, por tanto, la demostración de la capacidad de Amélie para hacer felices a los demás se produce cuando la camarera accede a la dirección del personaje: la cámara se traslada entonces a 
una de las calles más famosas de la rive gauche ${ }^{11}$ parisina, la rue Mouffetard (5 ${ }^{\text {ème}) ~[29: 49] . ~ D e ~ e s t a ~ f o r m a, ~ e s e ~ m o v i m i e n t o ~ d e l ~ p e r s o n a j e ~ p o r ~ e l ~ s u r ~ d e ~ l a ~}$ ciudad que comenzó en el 15ème, en el lado izquierdo del plano y que ha ido ascendiendo por esta parte de la urbe, pasando por el conocido Barrio Latino, encuentra su meta en el Institut de France ( $\left.5^{\mathrm{èm}}\right)$ y en la construcción que lo conecta con el Musée du Louvre: el Pont des Arts (5 ${ }^{\mathrm{ème}}$ y $1^{\mathrm{er}}$ ) [33:59]. Amélie, quien se siente "en total armonía consigo misma", como indica la voz en off [34:01], ha cumplido con su misión; por lo tanto, ya puede regresar a su espacio natural, a su barrio de origen: Montmartre.

Efectivamente, la cámara regresa al $18^{\mathrm{e} m e}$, pero, incumpliendo con lo que se indica en el recorrido del Sindicato, al menos, de acuerdo a lo mostrado en el montaje: como se ha comentado cuando se le ha analizado detenidamente, Amélie se encontraría acompañando al ciego a lo largo de la rue Lamarck, pero, en realidad, la escena fue rodada en la calle de Les deux moulins. Sin embargo, lo que se evidencia es que, efectivamente, después de haber conseguido su objetivo, el personaje regresa a su burbuja existencial alejándose de los peligros que habitarían el resto de la ciudad. Por el contrario, el recorrido de Amélie por la "ville lumière" solo ha comenzado, ya que, pocos minutos después encuentra el álbum de Nino iniciándose una nueva secuencia de localizaciones externas al distrito 18 .

Si se regresa más arriba, se descubre que ya se ha mencionado a la Gare du Nord (10 $\left.{ }^{\mathrm{èm}}\right)$ porque es la estación donde la protagonista coge el tren para ir a visitar a su padre. La lógica determina que, consecuentemente, el lugar al que llegaría después de pasar la noche en la población de su progenitor sería el mismo; sin embargo, conforme se desarrolla la narración se descubren detalles que revelan que, por algún motivo, la estación en la que Amélie se reencuentra con Nino y recoge su álbum, no sólo es la ya citada, también, la Gare de $1^{\prime}$ Est (10 $\left.{ }^{\mathrm{èm}}\right)$. Conectada en línea recta con la Place du Châtelet ( $1^{\mathrm{er}}$ y $\left.4^{\mathrm{ème}}\right)$ por los bulevares de Sebastopol y Strasbourg, esta estación, además de contar con un servicio de cercanías (RER) que conecta París con la banlieue, también

\footnotetext{
${ }^{11}$ París se encuentra dividida en dos grandes partes de acuerdo al paso del río Sena por su centro. De esta manera, la norte, denominada rive droite, acoge a los distritos 1-4 , 8-12 y 16-20; mientras que la gauche (sur) está constituida por los 5-7 y 13-15 ème y ha quedado caracterizada como la zona cultural y artística de la capital.
} 
ofrece trenes cuyo destino son regiones galas cercanas (Alsacia, Lorena y Champagne-Ardenne) y países extranjeros (Alemania, Austria, Bielorrusia, Italia, Luxemburgo, países balcánicos y Rusia).

De esta manera, el andén en el que desciende la protagonista pertenece a la Gare du Nord [39:16], caracterizado por las farolas con diseños circulares en su parte alta. El desenfoque del fondo de los planos siguientes impide determinar si el nuevo encuentro entre la pareja protagonista sigue desarrollándose en esta estación o en la vecina indicada; así, Vincent y de Saint-Exupéry concretan que, efectivamente, se trata de esta última (2005:172):

Amélie (Audrey Tautou) se encuentra por segunda vez con Nino (Mathieu Kassovitz) en la sala de los pasos perdidos de la gare de l'Est. Como ocurriera la primera vez, él está, de nuevo, intentando recuperar las fotos rasgadas que se encuentran al lado de un fotomatón. Es en esta escena donde se ve al corazón de Amélie, más enamorada que nunca, latir a través de su ropa. Mientras que ella le contempla pasmada, Nino reconoce, de repente, al 'fantasma del fotomatón' y corre en su busca. Es en el exterior de la estación donde Amélie recupera el álbum que Nino acaba de perder durante su carrera. Más tarde, Amélie organiza todo para que un técnico acuda a la misma sala (la sala de los pasos perdidos) para reparar un fotomatón que, supuestamente, está averiado. Simultáneamente, se cita con Nino con el objetivo de que descubra quién es, realmente, el 'fantasma de los fotomatones' $y$ de quien ella ya ha descubierto su identidad... ${ }^{12}$.

Antes de comentar con mayor detenimiento esta información, señalar que el desarrollo de la secuencia sigue teniendo lugar en las inmediaciones de la Gare de l'Est [40:08]: Nino aparece por uno de sus laterales (rue d'Alsace) y corre detrás del técnico del fotomatón. Lo que interesa de la cita anterior es que, como indican sus autores, este fragmento no es el único del largometraje que tiene lugar en las inmediaciones de la otra estación del 10ème; así como tampoco aquel en el que las dos gares dialogan. En líneas posteriores se comenta este aspecto con mayor detenimiento y analizando cómo se produce esa alternancia de espacios convirtiéndose en uno único, casi real, gracias al montaje y a la postproducción.

Después de encontrarse con el nuevo objeto, el álbum de Nino, Amélie regresa a Montmartre, al punto neurálgico de su existencia. Se establecen, así,

${ }^{12}$ Traducción del original M. Tovar. 
similitudes entre el descubrimiento de la caja infantil en su baño y este documento: si cuando aparece la primera, la camarera de Les deux moulins se interesa por descubrir quién es su dueño y empieza a realizar una pequeña investigación entre sus vecinos para saber su nombre; en este segundo ya conoce su identidad física, pero no tiene ningún tipo de información que le permita acceder a él; consecuentemente, y de momento, no puede alcanzar su objetivo. La vuelta al $18^{\text {ème }}$ se manifiesta trasladando la cámara al bar para, poco después, ubicarla en la Place des Abbesses [45:31], reconocible por la entrada al metro que ocupa la parte derecha del plano y el kiosko que se presenta en su lado izquierdo y que, si bien continúa implantado en las inmediaciones de la plaza, no ocupa esa misma posición a día de hoy, por lo que, posiblemente, fuera movido para el rodaje de la película (medida similar a la instalación de la cabina telefónica en el parque Louise-Michel, como ya se ha explicado).

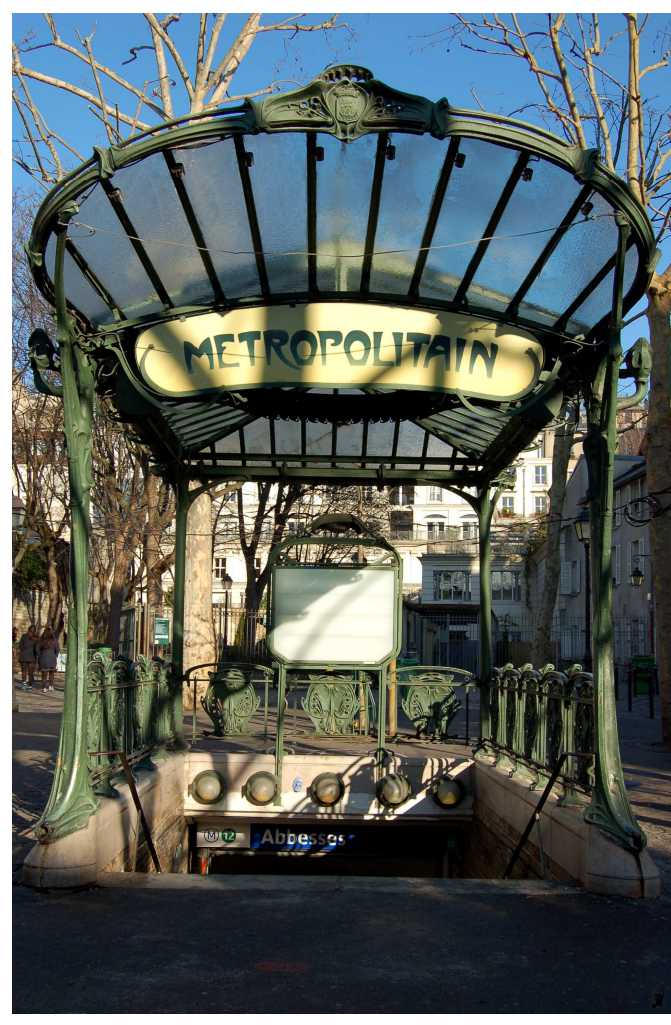

Fig 8. Entrada a la estación de metro $\mathrm{Ab}$ besses. (C) Foto Mónica Tovar
Concentrando el desarrollo narrativo a partir de este momento en el distrito mencionado, la cámara pasea por las localizaciones que lo habitan: el apartamento de Amélie que, a pesar de haberse construido, realmente, en un estudio de Colonia (Alemania) como el de los demás habitantes del inmueble dada la condición de coproducción de la cinta, se ubicaría en el número 56 de la rue des Trois Frères, como demuestra el plano del [49:38] al mostrar a la camarera saliendo de ese portal; su vecina espacial: la tienda de Collignon y la rue Lepic, donde se encuentra la ferretería en la que la protagonista realiza una copia de la llave de la casa del tendero. En relación a esto, cabe destacar que, una vez más, Jeunet le da la información de manera directa al espectador; ya 
que, componiendo un plano amplio [50:33], incluye en su parte derecha un letrero donde se aprecia el nombre "Lepic"; en su centro, un portal enunciado por el número 5 y a la izquierda, la entrada de la tienda en la que se informa del tipo de negocio que es. Por el contrario, y como ocurre con otros casos, si se busca una imagen actual del lugar, no hay correspondencia entre lo mostrado en la película y la realidad, reapareciendo los motivos de producción como causa y justificación de la misma.

Regresando a la Place des Abbesses, la cámara retoma, en una especie de ejercicio circular, localizaciones mostradas hace escasos planos: Les deux moulins, la tienda de Collignon, el edificio de Amélie... Hasta que vuelve a salir del distrito para instalarse en el único lugar exterior al $18^{\mathrm{èm}}$ al que se traslada habitualmente la protagonista: la vivienda de su padre. El fragmento queda acotado por la reubicación de la cámara en la Gare du Nord [55:55] que, como anteriormente, constituye su identidad fílmica combinando rasgos propios con otros de la del este. En este caso, el plano inicial vuelve a mostrar al andén con sus elevadas farolas, cediendo el testigo a uno que recoge, prácticamente, con la misma angulación, al fotomatón en el que Amélie se reencontró con Nino. La protagonista se encuentra en este momento con la información que necesitaba para erigirse como heroína, ya que, el joven ha dejado un anuncio reclamando su álbum. Se presupone que se inicia, por tanto, un nuevo recorrido por la ciudad que, como consecuencia, implicará el alejamiento de la cámara del $18^{\text {ème }}$.

Después de un breve fragmento filmado en el edificio de Amélie y en el que destaca la escena que se desarrolla en su habitación, ya que es donde se descubre el engaño al que se le está sometiendo al espectador debido a que, según el anuncio, Nino perdió el objeto delante de la Gare du Nord ${ }^{13}$ [56:21]; la cámara se traslada a la tienda y al bar. Se incumple, por tanto, la lógica que predomina en la parte anterior del largometraje que, sin embargo, queda justificada por la actitud de Amélie y es que, como se ha informado, no está preparada para hacerse cargo de la acción que se le habría "impuesto" al sentir algo por el joven protagonista.

\footnotetext{
${ }^{13}$ Se considera que, realmente, es un engaño espacial o de no correspondencia porque, según la voz en off del narrador, efectivamente, Amélie coge el tren que la lleva a la población de su padre en la Gare du Nord, pero, como se viene indicando, no es en esa estación donde se filman las imágenes.
} 
La cámara seguirá deambulando por el $18^{\mathrm{ème}} \mathrm{y}$ sus tradicionales localizaciones hasta que, después de que la joven hable con el hombre de cristal (quien, como se ha comentado previamente, es, en cierta manera, su incitador, el elemento clave para que decida alcanzar su objetivo y, consecuentemente, su deseo), se posiciona en el vecino 9ème, donde se encuentra el local erótico en el que trabaja Nino [1:06:00]. Mostrado como en la realidad, el Palace Vidéo es un negocio que ocupa, como muchos otros de sus mismas características, el bulevar de Clichy; sin embargo, se encuentra al lado del edificio con el portal número 37 y no del 74, como postulan Perez y Durant (2011: 74). De ese lugar, la cámara se traslada, supuestamente, a la feria del Trône [1:07:37]. Ubicada en la zona verde de Reuilly (12 $\left.12^{\mathrm{eme}}\right)$, realmente, fue suplantada por la de des Loges, que, anualmente, se celebra en la población de Saint-Germain-en-Laye, a veinte kilómetros de la capital. Aunque el realizador no ahonda en esta modificación en su comentario, posiblemente, tanto la época del año en la que se celebró el rodaje, como las condiciones establecidas para su desarrollo sean las principales explicaciones.

Poco después tiene lugar la que es, posiblemente, una de las secuencias más emblemáticas de Amélie y que se ha comentado más arriba: el nuevo encuentro entre la pareja protagonista y que tiene lugar en las inmediaciones del Sacré-Cœur. Comenzando en le Square Louise-Michel, la cámara asciende por los jardines ubicados a los pies del edificio religioso al seguir a Nino quien, igualmente, realiza el mismo recorrido que la mayoría de los turistas que se trasladan a esta zona de la "ville lumière". De este modo, lo que destaca de este momento del texto fílmico es que, precisamente, se desarrolle en el arrondissement identificado como propio de la protagonista: a pesar de haber cumplido con su función, Amélie no lo ha hecho con su objetivo, que es, además de la devolución del álbum, la aceptación de sus sentimientos por Nino. Así, el hecho de estar enamorada es lo que justifica que la camarera haya actuado dentro del perímetro de Montmartre, ya que, es allí donde consigue el valor suficiente para hacerlo, si bien, consecuentemente, niegue a la cámara el acceso a la zona exterior del mismo.

Lo que se produce a continuación es la sucesión de espacios reiterativos que, de la misma manera, se ubican, mayoritariamente, en el 18 ème, cumpliéndose, por tanto, la teoría de que, si la realización de la actividad implica el desplazamiento a otros espacios de la urbe, una vez cumplida, la protagonista 
regresa a su ubicación natural: después de la escena filmada en la vivienda del padre, la cámara se pasea por Les deux moulins, el Palace Vidéo, la tienda de Collignon y las diferentes plantas del edificio de Amélie hasta posicionarse en una estación que, dadas sus características, sería de trenes. Es, precisamente, en este momento, cuando el realizador desvela, en los comentarios del DVD, que [1:19:46]: Es la estación del Este, que mezclamos con la del Norte; nos inventamos una estación ideal mezclando las dos. Se confirma, por tanto, la hipótesis de que las escenas rodadas en las localizaciones ferroviarias son el resultado del diálogo de planos rodados en las dos comentadas, produciéndose una selección de sus espacios que son, consecuentemente, los que se ajustan al decorado ideado por el equipo de la película y que, igualmente, habría estado condicionado por permisos y características propias de la producción.

La siguiente secuencia en la que la cámara traspasa los límites de Montmartre recupera una localización ya comentada: la estación de metro La Motte-Picquet-Grenelle [1:22:27]. En este sentido, su reconocimiento, además de estar apoyado en la información ofrecida por Perez y Durant, encuentra parte de su justificación en su estilo arquitectónico: constituida por escaleras (que originan diversos niveles interiores) y columnas de gran tamaño fabricadas en materiales metálicos, es característica de las líneas de metro aéreas parisinas, por lo que, de nuevo, las posibilidades se reducen a, solamente, dos de ellas, como ya se ha defendido. Sin embargo, la cámara le niega al espectador la posibilidad de denominar perfectamente ese espacio, ya que ofrece planos en los que se reconocen los paneles informadores de los destinos de las vías, pero, no están enfocados, resultando imposible su lectura.

El fragmento posterior destaca porque, como ha ocurrido con otros ya analizados, aporta datos concretos al espectador quien, si lo desea, puede trasladarse a esos espacios directamente. En este sentido, se aprecia una diferencia importante y es que los subtítulos son menos completos que la voz en off de la versión original y que es la que determina perfectamente la ubicación de esos lugares, así como alude a elementos esenciales para el desarrollo narrativo. De esta manera, iniciándose en el [1:22:57], Amélie es presentada en el número 11 del bulevar Saint-Martin (3 y 10 ème), donde, realmente, también se encuentra una tienda de disfraces y en la que se introduce. En ese mismo momento, el "fantasma del fotomatón" aparece en la rue Lecourbe, en el número 108, regresando la cámara al 15ème, distrito donde se ha mostrado a personajes secunda- 
rios que, por el contrario, han tenido algún tipo de repercusión para la realización de las acciones de la protagonista. Tras esa separación de la misma, la cámara vuelve a ella y la acompaña en su llegada al fotomatón de la Gare de l'Est. La presentación de la estación se realiza de manera fragmentaria: comenzando por la escultura que corona su parte superior, se desplaza hasta el reloj que se encuentra en su fachada para, finalmente, abrir el plano y mostrarla de manera global, y es entonces cuando se descubre un nuevo engaño, ya que esa entrada es la de la vecina Gare du Nord. Si bien conforme se suceden los planos se sospecha la ausencia de correlación entre el espacio enunciado oralmente y lo presentado visualmente, también se aprecia el cuidado del equipo de postproducción de la película al haber modificado el término "nord" que ocupa la parte superior de las columnas por el de "est" para que el espectador no sea consciente del cambio producido. Sí se desarrollan en la estación enunciada oralmente las acciones posteriores (realización de instantáneas en el fotomatón por Amélie y llegada al recinto del técnico del sistema) reconocible por el reloj y el medio rosetón que decoran su parte superior.

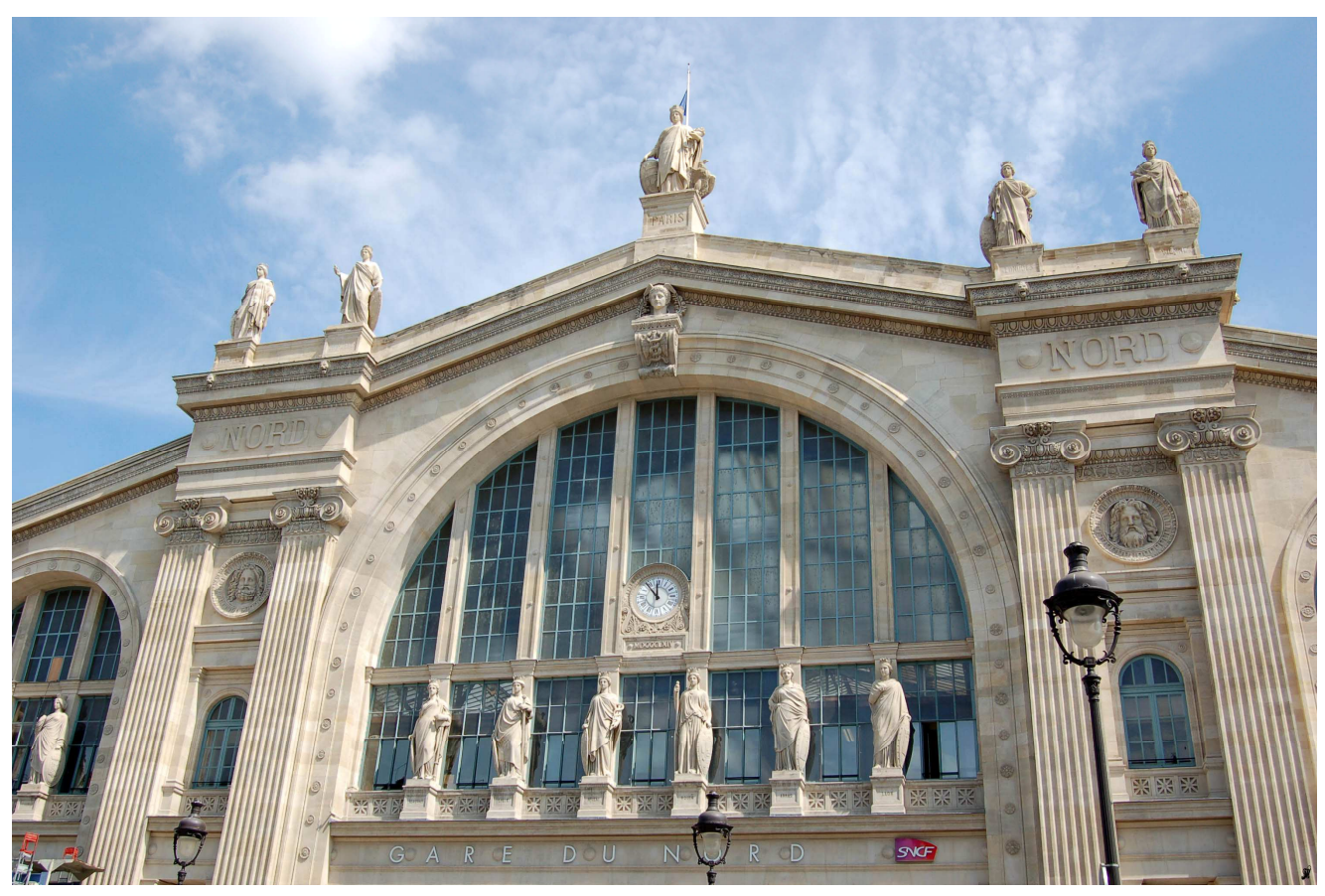

Fig. 9. Acceso a la Gare du Nord por la Place Napoléon III. @ Foto Mónica Tovar 
De nuevo, el descubrimiento de una información relevante para la protagonista es continuada por el regreso de la cámara al 18ème. Tras una serie de imágenes en las que se muestra a los diferentes vecinos de Amélie realizando diversas acciones, en la que también aparece un momento rodado en la vivienda de su progenitor y en la que se integra otro fragmento que se desarrolla en Les deux moulins, el espectador vuelve a ser trasladado a otros rincones de la "ville lumière" [1:29:54]: acompañando a Nino en la repartición de anuncios con los que busca reencontrarse con Amélie, la cámara muestra a un puente del metro aéreo, diversas calles de la ciudad por las que discurre montado en su ciclomotor, una estación de metro, igualmente, aéreo; la Place Denfert-Rochereau (14 ème, reconocible por la réplica de la escultura Le lion de Belfort de Auguste Bartholdi que recuerda la defensa nacional ejercida entre 1870 y 1871 contra los prusianos y que ocupa su centro) ${ }^{14}$, el interior de la Gare de l'Est y, finalmente, el Palace Vidéo.

De nuevo, en ese desarrollo narrativo que se sostiene sobre una secuencia circular en la que el $18^{\text {ème }}$ dialoga con el resto de la ciudad parisina de acuerdo a las acciones de Amélie, la historia vuelve a tener lugar en Montmartre, aglutinando a los personajes en Les deux moulins. De las siguientes secuencias, en las que la narración cede tiempo de expresión a sus historias secundarias, no destaca ningún aspecto, ya que tienen lugar en espacios ya comentados en varias ocasiones. Sin embargo, sí que presenta un mayor interés la nueva presentación de Amélie en la Gare de l'Est [1:37:01], ya que además de incluirse un plano en el que se vuelve a mostrar la fachada principal vista desde el interior, posteriormente, la propia protagonista, al realizar una llamada telefónica, indica que el fotomatón en el que se ha introducido se encuentra en la sala de los pasos perdidos (como, de hecho, se comentaba más arriba al incluirse la referencia de Vincent y de Saint-Exupéry). Asimismo, llama la atención que, cuando Nino acude a ese lugar, también citado por la protagonista, la cámara informa al espectador del punto concreto donde se ubica el servicio fotográfico: con un desplazamiento por la gran sala en la que se ubica, se reconoce el acceso principal [1:38:34] de la estación (Place du 11 novembre 1918), situándose el sistema, si el

${ }^{14}$ En este sentido, y teniendo en cuenta que, anteriormente, ya se ha relacionado a Nino con la estación de metro La Motte-Picquet, Grenelle, se considera que, posiblemente, la mayoría de las acciones exteriores de este fragmento se rodaron en las inmediaciones de los distritos 14 y 15 , al sur de París. 
viandante se dirige a las vías, en su lado derecho una vez superados los primeros arcos que constituyen la estructura interior del edificio. Actualmente, un fotomatón sigue ocupando ese lugar, aunque, dada la presencia de stands de diversas tiendas en la sala, no es fácilmente apreciable.

Los minutos finales del largometraje y que constituyen el desenlace de la narración, se erigen como una recapitulación de los espacios más determinantes para la historia de Amélie y, consecuentemente, como una especie de oda al barrio de Montmartre, y, por extensión, al 18 ${ }^{\text {ème }}$ que son quienes la protagonizan mayoritariamente. Les deux moulins, el hogar del padre, calles y escaleras de los alrededores del Sacré-Cœur, el edificio de la joven camarera, sus diferentes viviendas y la tienda de Collignon reaparecen en este momento determinándose como localizaciones capitales para la constitución de Amélie; pero, compartiendo minutos de manifestación con otros elementos también fundamentales para el desarrollo narrativo como el dueño de la caja infantil (mostrado en su casa) o la feria en la que trabaja Nino. Y en esa circularidad que caracteriza a la película de Jeunet, las imágenes finales no pueden tener otra procedencia que del $18^{\mathrm{ème}}$, caracterizándose por las calles empedradas que lo constituyen; ni tampoco negar la voz en off del narrador que realiza un ejercicio de presentaciones igual al que inauguraba el relato. Pero, asimismo, en ese paseo que realiza por Montmartre la pareja protagonista a lomos de la motocicleta de Nino, se reconocen espacios, detalles que permiten, grosso modo, describir el recorrido planteado [1:52:05]: de la rue Lamarck, reconocible por ser una de las que rodean a la plaza del Sacré-Cœur y presentar en su otra acera a varios establecimientos hosteleros, pasan a la de Saint-Vincent, introductora del relato y que se identifica por la pared decorada con arcos de piedra y un doble escalón en su lado izquierdo (si se la desciende); continuando por la rue du Chevalier de la Barre, que alberga la parte posterior de la famosa basílica y llegando a la rue Ronsard, también una de las que bordean el edificio cristiano y que se aprecia al integrarse en el plano la pared del halle (mercado) Saint-Pierre. Entre estas presencias, otras calles que, sin embargo, dado el movimiento de la cámara, la composición (con mayor protagonismo de la pareja) y el desenfoque del fondo de los planos donde aparecen, no son reconocibles, aunque, por algunos detalles, se considera que, posiblemente, muchas de las escenas en las que aparecen fueron rodadas en algunas de las previamente mencionadas. 


\section{El destino de Amélie: de la cabeza a los pies de París. Conclusiones}

Como se ha defendido en los epígrafes precedentes, el análisis fílmicourbano exhaustivo de una de las producciones más conocidas de Jean-Pierre Jeunet revela que, efectivamente, su relato, si bien potencialmente desarrollado en las dimensiones del $18^{\text {ème }}$ (con la ya indicada concentración espacial y narrativa en Les deux moulins, el Sacré- Cœur y sus alrededores, el edificio de Amélie y la tienda de Collignon), también cede tiempo de manifestación a los otros distritos que constituyen el París actual. Si se recapitulan las referencias manifestadas más arriba, de los 20 arrondissements en los que está distribuida la "ville lumière" desde 1860, únicamente cinco no están presentes: el 2ème, habitado por el edificio de la Bolsa; el $8^{\text {ème }}$, portador de dos de los iconos parisinos por excelencia: el Arc de Triomphe que, dada su posición en una rotonda, comparte

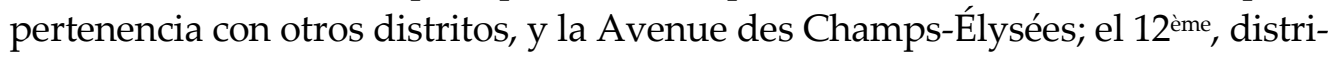
to no excesivamente turístico a pesar de contar con diversos puntos de interés y de gran importancia para la actividad social y cultural de la capital (la Cinémathèque Française, el Palais Omnisports de Paris-Bercy, el Viaduc des Arts o la Promenade Plantée, entre otros, además de la Gare de Lyon); el 13ème, caracterizado no sólo por contar entre sus edificios con el François-Mitterrand de la Bibliothèque Nationale de France (BnF), también porque uno de sus barrios congrega a una importante comunidad asiática (lo que ha implicado la aplicación del apelativo quartier asiatique) y el 17ème, vecino del segundo indicado y que, además de compartir con este una parte de la identidad del famoso arco, también encuentra dentro de sus dimensiones al Palais de Congrès de la ciudad. Sin embargo, este análisis y su consecuente resumen plantean una serie de problemas que se explican a continuación.

El primero de ellos es que, dada la distribución de la metrópoli y sus características constitutivas, algunos de los distritos se cuentan como presentes en el largometraje porque alguna de las calles o de los elementos que los habitan aparecen en él, pero, con el distintivo de una pertenencia colectiva; es decir, su ubicación implica que sea entendido como miembro de dos o más arrondissements (son los casos del Pont des Arts y de la estación de metro Porte-desLilas). Otro caso similar se produce con la presencia de iconos o referentes emblemáticos; concretamente, con la Tour Eiffel. Mostrada en un plano general rodado a bastante distancia de su ubicación real, su presencia en pantalla hace que el turista-espectador piense en el 7ème, área urbana en la que se encuentra. 
Aunque la cámara no se traslada a la misma, el hecho de que la estructura aparezca en el montaje implica la integración de su distrito en el plano de la metrópoli que recrea la película, sobre todo, al tenerse en cuenta, precisamente, que es uno de los distintivos de la "ville lumière" y que, como ya se ha comentado, es de inclusión prácticamente obligatoria para el anclaje geográfico de la historia contada. Un ejemplo cercano a este se plantea con respecto al $12^{\mathrm{ème}}$, pero, en sentido contrario: introducido por la voz en off del narrador, como ya se ha explicado, realmente no está presente en el relato, ya que el rodaje en la feria que se encuentra en él fue trasladado a la de des Loges, a las afueras de la capital. De esta manera, la referencia oral, prácticamente, obliga a aceptar esa presentación, ya que, como orador, conocedor del relato, la figura del narrador es entendida por el consumidor del mismo como una fuente de información veraz, que no debería mentirle; aceptándose, consecuentemente, como verdaderos todos los datos que aporta. Sin embargo, y partiendo de la premisa de que Amélie se erige como una guía turística, se ha considerado inadecuado aceptar tal presentación, ya que, además del engaño subyacente, los minutos dedicados a la feria son escasos (el protagonismo reside, sobre todo, en el interior de una atracción), por lo que, posiblemente no es uno de los lugares que podría suscitar interés en el turista-espectador. Igualmente, y en este sentido, no se puede pasar por alto el tratamiento que Jeunet le ha dado a los diferentes espacios por los que deambulan sus personajes y en los que se posicionó la cámara: además de la aplicación de una estética específica ya comentada, el cineasta galo trabajó la composición de sus planos para que estos se ajustaran a la imagen de la ciudad que quería ofrecer de su urbe y, más concretamente, de su distrito. De este modo, junto a los decorados reales reconocibles aparecen otros también existentes, pero cuya identidad ha sido modificada para que se adapten mejor a las características del relato (por ejemplo, el caso de las estaciones de metro). El realizador sigue, así, una de las tendencias de la cinematografía francesa iniciada la década anterior, como postula N. T. Binh (2005: 210):

Herederos de la Nouvelle Vague, muchos cineastas de los años 90 rehacen de París el decorado de una geografía romántica inédita. Menos ritualizado que el de sus predecesores, este nuevo mapa imaginario está formado, a veces, por lugares claramente identificados, pero, no hay nada más irreduciblemente parisino: las preocupaciones de los personajes, sus frecuentaciones así como sus hábitos, nos trasladan irremediablemente a la capital (trad. del original M. Tovar). 
De esta manera, estas modificaciones implican que, como se ha defendido en las líneas precedentes, a priori, algunos de los espacios sean atribuidos a unos barrios o distritos en los que, realmente, no se encuentran; haciendo considerar que la cámara ha recorrido un menor espacio urbano del que ha filmado. Asimismo, esos cambios también pueden ocasionar dudas en el espectador, quien al buscar el espacio fílmico, no encuentra a su igual en la ciudad real (como es el caso de la estación ferroviaria nacida de la combinación de dos existentes). Así, vuelve a ser Binh el autor que identifica en esta estrategia de Jeunet otra de las características de la filmografía gala contemporánea al indicar que (2005: 212):

Abandonando todo naturalismo, algunos cineastas se apoderan de París para crear una ciudad irreal, casi fantástica: espantosa o embrujada, la capital hechizada ofrece una cara inédita en el cine contemporáneo que restablece cierta tradición francesa, de Louis Feuillade a René Clair (trad. del original M. Tovar).

Esta constitución de una nueva metrópoli a partir de una ya existente es reconocida por el mismo cineasta quien, en el pressbook de la película (consultable en su edición castellana en la página web de la distribuidora -Vértigo Films-), explica no sólo esa búsqueda de un París estéticamente cercano al mostrado por Tardi, como ya se ha comentado, también, la eliminación o sustitución de ciertos elementos urbanos (graffitis y carteles) con el objetivo de conseguir la ciudad imaginada. Sin embargo, todos estos cambios vuelven a remitir a una cuestión ya planteada y es la situación a la que se enfrenta el turista-espectador cuando accede a la realidad inspiradora de la ficción. Se perfila, de esta manera, una posible línea analítica en la que el objeto principal son, precisamente, las repercusiones que tiene para el elemento urbano la imagen que se proyecta del mismo en las creaciones artísticas y, en concreto, en las cinematográficas. La metrópoli, mostrada de acuerdo a diferentes variables y modelos (narratológicos, autorales, de género, etc.), es aceptada por el espectador como real quedando determinadas su comprensión, valoración y creación del imaginario urbano por ese modelo. La problemática surge cuando, como ocurre con el caso de Amélie, la imagen fílmica no es plenamente coincidente con la real; es, así, cuando surgen las preguntas sobre cómo ese modelo proyectado influye en la percepción de la realidad de la ciudad por el turista-espectador, cómo este se enfrenta a la misma y cuáles son las conse- 
cuencias directas de su enfrentamiento con ese diseño habitable, palpable, generador de esa otra o segunda realidad que ha constituido la cinematográfica.

En cuanto a la película que da título a este artículo, finalmente, comentar que, si bien en algunos países es conocida como Amélie de Montmartre, lo que propicia la visita de los turistas-espectadores al quartier enunciado, las estrategias desarrolladas, fundamentalmente, por el Sindicato de Iniciativa del mismo han propiciado el establecimiento de una unión prácticamente imposible de desligar entre el texto fílmico y el enclave urbano. De la misma manera, las localizaciones reales se han beneficiado de su presencia en la narración de Jeunet, no sólo al aparecer en parcours o en otros materiales consumidos por los visitantes interesados en la identidad cinematográfica de la "ville lumière", también porque ellas mismas potencian esa característica al mantener elementos que remiten, directamente, a la creación. Beneficios compartidos, por tanto, entre unos espacios necesarios para la producción del elemento cultural y una creación que envía al turista-espectador a enclaves concretos de la metrópoli. Asimismo, esa ciudad que, dada la acotación referencial del título del largometraje y el anclaje de su protagonista a un distrito específico, podría haber quedado determinada a una extensión concreta, se muestra de manera global y completa: global porque, como se ha explicado, prácticamente todos sus arrondissements han sido capturados por la cámara y completa porque junto a sus iconos, sus emblemas, aparecen otras zonas menos transitadas, al menos, por los visitantes.

Esta coexistencia de espacios en la película, realmente manifestación verdadera de la identidad urbana, es más que relevante en cuanto al consumo del turista-espectador: incitado por el deseo de revivir las situaciones protagonizadas, sobre todo, por la pareja principal (y de manera más destacada por la joven camarera), se trasladará a todos esos lugares que los diferentes planos le han mostrado, produciéndose con ese desplazamiento por la metrópoli, como previamente se ha defendido, un acceso a esas otras áreas menos conocidas. Como consecuencia de esta acción, lo que se aprecia es que, aún sin haberse constituido como objetivo primario, Jeunet, quien habría querido rodar una película centrada en su barrio, en Montmartre, traslada varias de sus acciones a otras zonas de la capital gala determinado por las características, los rasgos, el aspecto estético del que quería dotar a su ciudad imaginada. Consecuentemente, el turista-espectador es invitado a adentrarse en la "ville 
lumière" accediendo a una identidad urbana compleja en la que, además de los referentes emblemáticos, fundamentales para su constitución, su reconocimiento y su diferenciación de otras ciudades potencialmente fílmicas, existen otros lugares que, igualmente, son imprescindibles para su diseño, su configuración. París como un gran decorado cinematográfico en el que todos sus rincones pueden erigirse como potenciales localizaciones en las que se desarrollan los actos de los diferentes personajes; distinción que explica no sólo el caso de la pluralidad espacial de las diferentes secuencias de Amélie, también que sea una de las ciudades más filmadas del mundo y que, siendo consciente de ello, haya sabido explotar esta cualidad en términos turísticos y, al mismo tiempo, cinematográficos revelándose como una metrópoli que en cada rodaje tiene algún rincón nuevo que mostrar.

\section{Bibliografía citada y consultada, videografía y webgrafía}

BINH, N. T. (con la colaboración de GARBARZ, Franck) (2005): Paris, au cinéma. La vie rêvée de la capitale de Méliès à Amélie Poulin. Parigramme. París.

CLADEL, Gérard et al. (dir.) (2001): Le cinéma dans la cité. Éditions du Félin. París.

DeSCURE, Virginie y CASAZZA, Christophe (2003): Ciné Paris. 20 balades sur des lieux de tournages mythiques. Hors Collection. París.

FlAMAND, Thierry (1994): “Adapter la ville à l'écran" en NINEY, François (dir.) Visions urbaines. Villes d'Europe à l'écran. Centre Georges Pompidou. Colección Cinéma/Singulier. París.

GANNE, Valérie; JULliARD-MOURGUES, Caroline y PRIOT, Franck (2009): Tourisme et tournages de films. Comment dynamiser son territoire par l'audiovisuel (Mini-guide). ODIT (Observation, Développement et ingénierie touristique) France y Commission Nationale du Film-Film France. París.

JeuneT, Jean-Pierre (2002): Amélie [DVD]. Vértigo Films. Madrid.

PereZ, Vincent y DurANT, Philippe (2011): Le Paris du cinéma. Guide illustré de la Ville Lumière. 800 adresses liées au septième art. Éditions Favre. Lausana y París.

SERVEL, Alain (1987): Frenchie goes to Hollywood. La France et les français dans le cinéma américain de 1929 à nos jours. Éditions Henri Veyrier. París. 
VINCENT, Marie-Christine y de SAINT-EXUPERY, François (2004): Paris vu au cinéma. Le premier guide touristique dévoilant les lieux de tournage de 300 films de référence. Movie Planet. París.

VV. AA. (2010): Document de la présentation de la Mission Cinéma. Paris Film. Mairie de Paris. París.

Todas las páginas web han sido consultadas de nuevo para verificar su actual disponibilidad y por última vez el 14/02/2013.

http://www.fetedesloges.org

http://www.foiredutrone.com/

http://www.imdb.fr/title/tt0211915/?ref =sr 1

http://www.paris.fr/loisirs/paris-et-le-cinema/mission-

cinema/rub 8358 stand 36017 port 19409

http://www.paris.fr/loisirs/paris-et-le-cinema/parcours-

cinema/rub 8358 stand 11911 port 19409

http://www.vertigofilms.es/catalogo-peliculas/a/amelie.html 